University of Nebraska - Lincoln

DigitalCommons@University of Nebraska - Lincoln

Spring 2018

\title{
Bird Population Changes Following the Establishment of a Diverse Stand of Woody Plants in a Former Crop Field in North Dakota, 1975- 2015
}

Lawrence D. Igl

Harold A. Kantrud

Wesley Newton

Follow this and additional works at: https://digitalcommons.unl.edu/usgsnpwrc

Part of the Animal Sciences Commons, Behavior and Ethology Commons, Biodiversity Commons, Environmental Policy Commons, Recreation, Parks and Tourism Administration Commons, and the Terrestrial and Aquatic Ecology Commons

This Article is brought to you for free and open access by the US Geological Survey at DigitalCommons@University of Nebraska - Lincoln. It has been accepted for inclusion in USGS Northern Prairie Wildlife Research Center by an authorized administrator of DigitalCommons@University of Nebraska - Lincoln. 


\title{
Bird Population Changes Following the Establishment of a Diverse Stand of Woody Plants in a Former Crop Field in North Dakota, 1975-2015
}

\author{
Lawrence D. Igl, Harold A. Kantrud, and Wesley E. Newton
}

\begin{abstract}
Changes in the coverage of trees and shrubs on the North Dakota landscape since Euro-American settlement have likely had a pronounced impact on bird species that favor woody vegetation. Long-term data sets on breeding bird populations in wooded habitats in North Dakota or in the Great Plains are scarce. In 1975 a wildlife habitat plot was established in a 10.5 ha cropland field with a long history of small-grain production. The objective of this article is to evaluate the successional changes in bird populations as the habitat at this site became more biologically and structurally complex after the establishment of a diverse stand of shrubs and trees. Between 1975 and 2015, 103 species or varieties of native and non-native trees, shrubs, or vines were planted in this wildlife habitat plot (hereafter woodlot); $58.2 \%$ of those species were still present in 2016 . The avian community in the woodlot increased in abundance and diversity as the woody vegetation increased in complexity and maturity, but the changes in abundance varied among ecological bird groups. Grassland bird abundance remained relatively constant but uncommon throughout the four decades after woody vegetation was first established. Bird species associated with shrublands and open woodlands and edges responded positively and showed the greatest increases in abundance during the 41-year period. The abundance of bird species associated with open areas with scattered trees or shrubs (i.e., savanna habitat) increased during the first half of the study but declined during the second half. Bird species associated with forest habitats were rare throughout the 41-year period, but their abundance increased during the most recent two decades. Results of this study are important for informing decisions about restoration efforts of riparian forests and other native wooded areas in the Great Plains and setting expectations for the time-scale required for the return of assemblages of species of woodland birds.
\end{abstract}

Key Words: birds, colonization, grassland, habitat diversity, North Dakota, population changes, shrubland, successional changes, woodland

\section{Introduction}

North Dakota is in the northern Great Plains of North America, where low annual precipitation, extreme temperature fluctuations, strong winds, and periodic droughts provide a relatively hostile environment for trees, shrubs, and other woody vegetation (Wright 1970; Haugen et al. 1999). Stewart $(1975,4)$ described the North Dakota landscape before settlement as "great uninterrupted expanses of nearly treeless prairie." Reports from early explorers indicated that trees and shrubs were primarily restricted to river floodplains, east-facing and north-facing bluffs along streams, and prominent hillsides (Reid 1948; Stewart 1975; Hart and

Great Plains Research 28 (Spring 2018):73-90.
Hart 1997). Jakes and Smith (1982) estimated that about $2,830 \mathrm{~km}^{2}$ of forest land or roughly $1.5 \%$ of the total area of North Dakota was covered by forest at the time of Euro-American settlement, which began in earnest after the US Congress organized the Dakota Territory in 1861.

Euro-American settlement brought drastic changes to the North Dakota landscape. The shortage of wood for fuel, fencing, housing, and protection was discouraging to early settlers (Hart and Hart 1997), and triggered repeated efforts to establish tree plantings in the state. Since settlement, North Dakota has lost about $49 \%$ of its wetlands (Dahl 1990, 2014) and 75\% of its native prairies (Samson and Knopf 1994), almost entirely because of conversion to agriculture. Although native riparian forests and woodlands also have declined in North Dakota and the northern Great Plains since settlement (Stewart 
1975; Johnson et al. 1976; Hesse 1996; Dixon et al. 2012), the overall abundance and distribution of woody vegetation have changed dramatically. Woody vegetation has become increasingly more common in the state as exotic species and hardier varieties of native trees and shrubs have been planted in windbreaks, shelterbelts, and urban and residential areas (Haugen et al. 1999). In addition, the suppression of prairie wildfires and extirpation of native ungulates, which historically limited the growth of woody vegetation, have resulted in the encroachment of native and non-native trees and shrubs into open grasslands (e.g., Grant and Berkey 1999).

Changes in the coverage of trees and shrubs on the North Dakota landscape since settlement have had a pronounced impact on bird species that favor woody vegetation, leading to changes in their abundance and shifts in their distribution (Igl and Johnson 1997). Although natural riparian corridors in this region have been extensively developed, altered, regulated, or degraded since settlement (NAS 2002), woodlots of anthropogenic origin have the potential to partially substitute for lost and degraded riparian woodland habitat for birds that favor woody vegetation (e.g., Cassel and Wiehe 1980; Yahner 1982, 1983; Liu and Swanson 2014a, 2014b). Temporal change in avian diversity and abundance in anthropogenic woodlands as the woodlands mature has been poorly studied in the northern Great Plains. Moreover, compared with eastern deciduous forests (e.g., Johnston and Hagan 1992), long-term data sets on breeding bird populations in wooded habitats in North Dakota or in the northern Great Plains are scarce (e.g., Schwilling 1982; Johnson and Beck 1988).

In 1975 Harold A. Kantrud established a wildlife habitat plot (hereafter "Kantrud's Woodlot") in a 10.5 ha cropland field with a long history (since at least 1951) of small-grain production. In particular, Kantrud wished to maximize the number of woody plant species and the number of stands of those species, and minimize the proximity of woody vegetation to grassy openings and winter food plots by clustering the woody vegetation together into stands. This article outlines the temporal or successional changes in breeding bird populations that occurred in Kantrud's Woodlot during the four decades (1975-2015) that ensued as the habitat at this site became more biologically and structurally complex after the establishment of a diverse stand of shrubs and trees.

\section{Study Area}

Kantrud's Woodlot lies in southeastern Stutsman County ( $46^{\circ} 51$ ' $\mathrm{N}$ latitude, $98^{\circ} 35^{\prime} \mathrm{W}$ longitude) in the Southern Drift Plain of the Prairie Pothole Region, about $10 \mathrm{~km}$ southeast of Jamestown and $1.5 \mathrm{~km}$ west of the James River. Soils at the site are dominated by SveaBarnes loams, which typically occur on level (o\%-3\%) or nearly level (3\%-6\%) till plains (Abel et al. 1995). Svea and Barnes soils are both black loams with $0.18-0.20 \mathrm{~m}$ surface layers and 0.56-0.64 m subsoil layers. Svea and Barnes loams are suitable to all or nearly all climatically adapted trees and shrubs grown as windbreaks and environmental plantings in this region. The southern and eastern boundaries of the woodlot are adjacent to a multiple-row farmstead windbreak ( $2 \mathrm{ha}$ ) that was planted by the previous landowner in 1951, but birds were not surveyed in this windbreak. The western border of the woodlot occurs along a gravel road, and the northern boundary borders a fenced pasture.

In 1975 Kantrud developed a map of the planned tree and shrub plantings at a scale of 100 feet $(30.5 \mathrm{~m})$ to 1 inch $(2.54 \mathrm{~cm})$, and in March 1975 Kantrud presented his design to the staff of the Stutsman County Soil Conservation District (SCD) (Fig. 1). The wildlife habitat plot included woody plantings as well as grassland openings and, in the first 10 years, wildlife food plots (planted sporadically through time to corn [Zea mays], red clover [Trifolium pratense], buckwheat [Fagopyrum esculentum], millet [Paniceae], or sunflower [Helianthus]). In later years, perennial grasses, forbs, and small-tomedium shrubs were allowed to take over the wildlife food plots. In May 1975, the Stutsman County SCD machine-planted into flax stubble (from the 1974 growing season) nearly 18,000 trees and shrubs of 38 species or varieties (Appendix A) along multiple rows totaling $22,433 \mathrm{~m}$ in length in 6 ha of the 10.5-ha site. Woody species were initially selected based on their hardiness and tolerance to North Dakota's harsh climate (i.e., long and cold winters, extreme fluctuations in precipitation and temperature, strong winds), the availability of planting stock, and their relative value for wildlife habitat, cover, and food. Individual trees and shrubs were grouped into blocks that were five rows wide and $45.7 \mathrm{~m}$ long along curves originating from the four corners of the plot. The long, curved lines were designed to reduce the vulnera- 


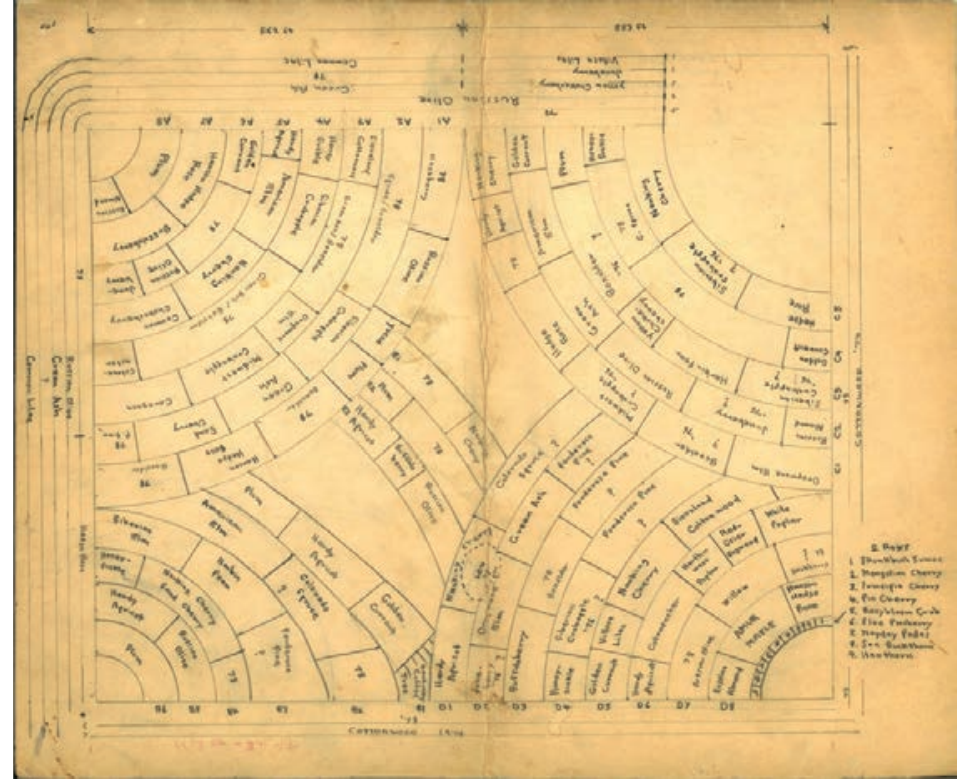

Figure 1. Original map of the 10.5 ha wildlife planting in Stutsman County, North Dakota (with minor alterations to show some later replantings and additions), developed by Harold A. Kantrud in March 1975. North is toward the top of the map.

bility of wildlife to avian and mammalian predators and human hunters (Figs. 1 and 2). Woody plant species were alternated as much as possible between rows, and the location of the species were adjusted such that their height at maturity would gradate from tall to short toward the edges of three grass openings in the plot. In a ceremony on 16 May 1975 at Kantrud's Woodlot, the Stutsman County SCD celebrated the planting of its five millionth tree since the organization's inception in 1948.

Between 1976 and 1979, an additional 14,160 m of trees and shrubs were machine- or hand-planted to supplement the original plantings or to replace many trees and shrubs that did not survive (due to drought or damage by rodents or lagomorphs) since the 1975 planting. Additional tree, shrub, or vine species were hand-planted between 1980 and 2016 (Fig. 2). These later plantings included woody species that are adapted to milder climates but have a higher chance of survival when planted in an established stand of other woody plants. Mechanical weed control (i.e., tandem disc, spring-tooth harrow) was employed during the first 10 years after establishing woody vegetation. The grassland openings and the understory of the woodlot are dominated by smooth brome (Bromus inermis). Vernacular and scientific plant names follow the Integrated Taxo-

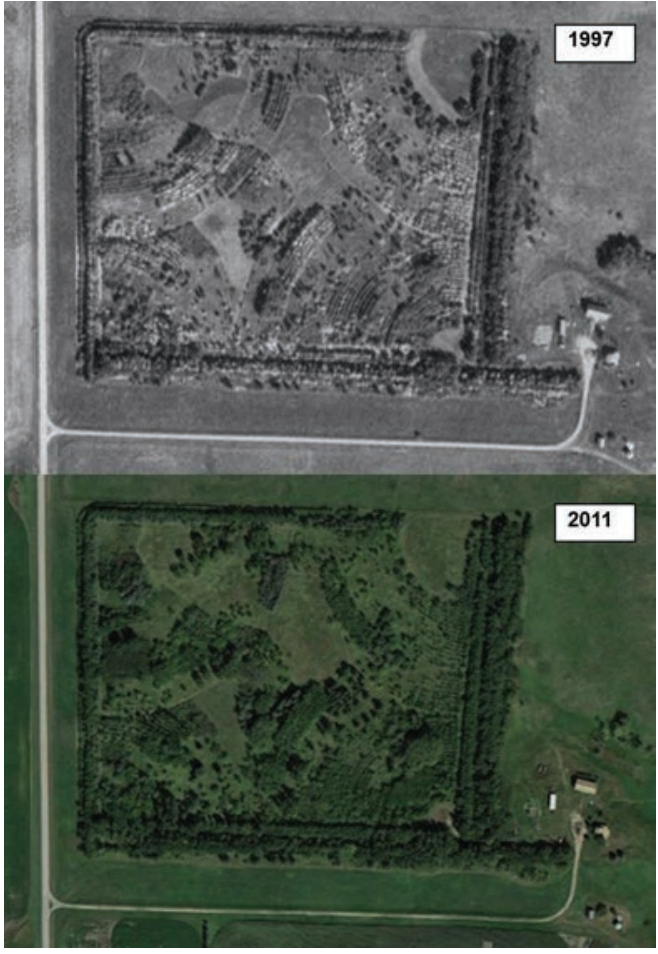

Figure 2. Aerial images of Kantrud's Woodlot in Stutsman County, North Dakota, in September 1997 (after a hailstorm) and September 2011. Aerial photos from Google Earth ${ }^{\circledast}$. North is toward the top of the photos.

nomic Information System (http://www.itis.gov) or, in a few cases, the US Department of Agriculture's Plants Database (http://plants.usda.gov/).

\section{Methods \\ Breeding Bird Surveys}

A total-area count of breeding birds was conducted once annually from 1975 to 2015 during the peak breeding season (i.e., late May to early July; Stewart and Kantrud 1972; Igl and Johnson 1997) by one experienced observer, who walked random paths through the entire study plot and recorded all birds seen or heard. No surveys were conducted in 1985. A total-area count allows a fairly rapid assessment of the breeding bird community of the area, but in contrast to conventional point counts, the total-area count covers the entire study site. Area-count methods have been used by many researchers to characterize an entire breeding bird community in a predefined study area (e.g., Stewart 
and Kantrud 1972; Slater 1994; Dieni and Jones 2002; Watson 2003, 2004). For some large-bodied species (e.g., waterfowl, upland game birds, raptors), the annual surveys were supplemented by incidental observations during the peak breeding season.

Observers identified bird species by sight or sound. We avoided conducting bird surveys during precipitation and strong winds $(>8 \mathrm{~km} / \mathrm{h})$. We conducted surveys of birds between $0.5 \mathrm{hr}$ after sunrise and 10:00 CST; the average bird survey was 112 minutes $( \pm 43 \mathrm{~min}[\mathrm{SD}])$. Counts of breeding birds were based on the numbers of indicated breeding pairs during the peak breeding period (i.e., late May to early July) in North Dakota; the average survey date was 13 June ( \pm 6.2 days [SD]). For most species, nearly all indicated pairs were observed as segregated pairs or as territorial males. We did not consider certain birds observed during the censuses to be breeding and excluded them from our results. These included species that would be unlikely to nest in the study area (e.g., cliff swallow [Petrochelidon pyrrhonota] and barn swallows [Hirundo rustica]); migrant flocks and individuals of species that are not known to breed in North Dakota; wide-ranging colonial waterbirds passing high overhead (e.g., pelicans and gulls); and other birds passing overhead in high, direct flight. Active or abandoned nests were noted during the surveys. Vernacular and scientific bird names follow the American Ornithologists' Union (1998) and subsequent supplements; scientific names of birds observed in this study are included in Appendix B. Bird survey procedures conformed to recommendations, science-based standards, and best research practices of the Ornithological Council (Fair et al. 2010) for the study of wild birds.

For discussion purposes, we categorized each of the observed bird species into a general breeding habitat association based on the literature (Ehrlich et al. 1988; Peterjohn and Sauer 1993; Igl and Johnson 1997) and personal experience (Appendix B). Habitat associations reflected different levels of structural complexity, ranging from early successional to later successional ecosystems. Habitat associations were described as (1) grassland, (2) shrubland, (3) open habitat with scattered trees or shrubs, (4) open or semi-open deciduous woodland and edge, and (5) forest. Species typically associated with wetland habitats (e.g., upland-nesting waterfowl) were categorized as grassland species, given that there are no wetland habitats in Kantrud's Woodlot and that these species typically nest in open grasslands. Secondorder (quadratic) polynomial regression methods were used to illustrate nonlinear relationships between year and bird abundance or species richness, following methods described by Kutner and others (2005).

To assess effectiveness of sampling species richness across years, we analyzed the accumulation of bird species in relation to the degree of sampling (i.e., the number of years) using PC-Ord software, version 6.0 (McCune and Mefford 2011). Four common nonparametric estimators of asymptotic species richness were calculated using the Sorensen (Bray-Curtis) distance measure as a coefficient and the default settings in PCOrd: First-order Jackknife richness estimator (Jackknife 1), Second-order Jackknife richness estimator (Jackknife 2), Chao 2 richness estimator (classic form), and Chao 2 richness estimator (bias corrected). The performance of the four estimators varies considerably, and is influenced by true species richness and the percentage of rare species in the breeding bird community (Chazdon et al. 1998; Gotelli and Colwell 2010). The estimators reflect that species not yet sampled will always be rare, and thus their numbers can be predicted by analyzing the relative frequency of rare species already present in samples. The Jackknife 1 estimator depends on the species found in only one sample, and the Jackknife 2 estimator depends only on the species found in two samples. Chao 1 is an abundance-based estimator of species richness that relies on the number of singletons and doubletons (i.e., species represented by one and two individuals), and Chao 2 is an incidence-based estimator that uses the number of unique units and duplicates (i.e., species found in only one and two sample units) (Chazdon et al. 1998).

\section{Vegetation and LiDAR Acquisition and Processing}

Vegetation changes were not systematically monitored during the study period, although Kantrud occasionally measured height and percentage survival of woody species within blocks and noted the general survival of woody species through time. In 2016 we visited the woodlot to confirm survival of species of woody vegetation planted between 1975 and 2015 (Appendix A).

To characterize vegetation heights and vertical profiles within the woodlot, we used airborne Light Detection and Ranging (LiDAR; Vosselman and Maas 2010) data that were acquired in the fall of 2010 as part of the James River Watershed Mapping project of the US Army Corps of Engineers (St. Louis District) to reduce flood damage and protect natural resources in the James River watershed basin. The LiDAR flights for that project 
occurred between 15 October and 27 November 2010, a period when deciduous species within this region would be mostly leaf-off (i.e., already have shed their leaves). We downloaded the raw three-dimensional point-cloud LiDAR data as LAS 1.2 formatted files (http://lidar.swc .nd.gov/; accessed on 14 July 2016), which were then converted to text files for further processing. We extracted LiDAR data in a $360 \times 300 \mathrm{~m}$ block (UTM zone 14; NAD83-2007; NAVD88; lower left corner of acquisition area: $531565 \mathrm{E}, 5187167 \mathrm{~N}$ ) that covered the entire woodlot in which bird surveys occurred. In general, the nominal post-spacing of the LiDAR was $1.4 \mathrm{~m}$. To classify the LiDAR return data into ground or nonground points, the raw LiDAR data were processed using a minimum mean block algorithm (Zhang and Whitman 2005). The ground-classified points were used to generate a $1 \mathrm{~m}$ digital elevation model (DEM). We computed the vegetation heights aboveground by subtracting the DEM from the nonground points (i.e., vegetation) within the $1 \times 1 \mathrm{~m}$ cells across the woodlot. Given that LiDAR data tend to have a vertical accuracy of $\pm 0.1 \mathrm{~m}$, we considered heights above ground that were less than $0.25 \mathrm{~m}$ to be ground or short grasses and forbs.

To estimate the heights above ground in the woodlot in 2016 from the leaf-off LiDAR data from 2010, we collected tree and shrub heights greater than $0.25 \mathrm{~m}$ in the woodlot in July 2016 at 27 strategic sampling points that covered a broad range of vegetation heights (minimum $=0.25 \mathrm{~m}$, maximum $=18.0 \mathrm{~m}$ ). Using a buffer of $2.5 \mathrm{~m}$ around each of the 27 sampling points (i.e., to accommodate horizontal accuracy in both the LiDAR data and the field UTMs), we regressed the field-height measurement with the maximum heights-aboveground point within the buffer to derive a recalibration function:

$$
y=1.38846 x-0.01633 x^{2}
$$

where $y=$ field height and $x=2010$ LiDAR heights aboveground, which assumes that ground remained mostly ground between 2010 to 2016 . We then adjusted all of the nonground classified points to better represent the 2016 shrub and tree characteristics. To calculate summary statistics of the entire woodlot, we stratified the $360 \times 300 \mathrm{~m}$ woodlot into nonoverlapping $10 \times 10 \mathrm{~m}$ cells ( $n=1,080$ total cells; hereafter 10 m cells).

Within each $10 \mathrm{~m}$ cell, we computed proportions of returns in six vertical bins that reflected the vegetation stage of vertical height: returns of zero reflected ground, returns of o-1 m reflected short shrubs or grass/forbs,

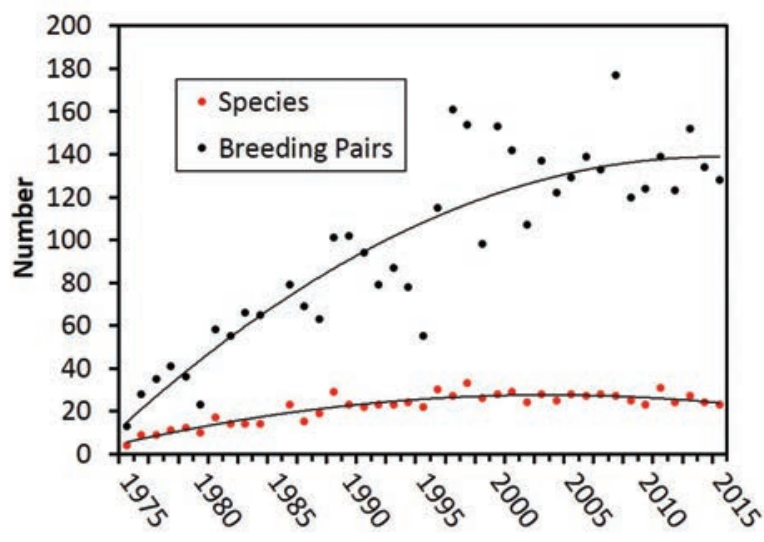

Figure 3. Changes in the observed number of bird species and indicated breeding pairs at Kantrud's Woodlot in Stutsman County, North Dakota, between 1975 and 2015.

1-2 $\mathrm{m}$ reflected tall shrubs, 3-6 $\mathrm{m}$ reflected short trees, 6-12 $\mathrm{m}$ reflected trees of medium height, and greater than $12 \mathrm{~m}$ reflected tall trees. We used the FASTCLUS clustering procedure of SAS, version 9.4 (SAS Institute, Inc., Cary, North Carolina) to group the 1,080 $10 \mathrm{~m}$ cells into nine a priori vertical profile clusters using the proportions in the six vertical-height bins as the clustering variables. For summary purposes, we computed and then averaged the proportion of returns within 12 vertical profiles. We then calculated the number of $10 \mathrm{~m}$ cells that would be typified by a vertical profile to assess the various vertical profiles within the woodlot.

\section{Results \\ Breeding Bird Populations}

We recorded 62 species of breeding birds in Kantrud's Woodlot between 1975 and 2015 (Appendix B). Eighteen bird species are associated with grasslands, seven species with open areas with scattered trees or shrubs (i.e., savanna habitat), 22 species with open or semi-open woodlands and edge habitats, seven species with shrublands, and eight species with forests. Most (85\%) of the 62 species are migratory, and only a few species (gray partridge, sharp-tailed grouse, ring-necked pheasant, wild turkey, great horned owl, long-eared owl, downy woodpecker, hairy woodpecker, and black-capped chickadee) are considered permanent year-round residents that show little or no seasonal movements in North Dakota (Igl and Johnson 1997). Moreover, migrants constituted over $92 \%$ of the total number of indicated pairs detected each year in Kantrud's Woodlot. 


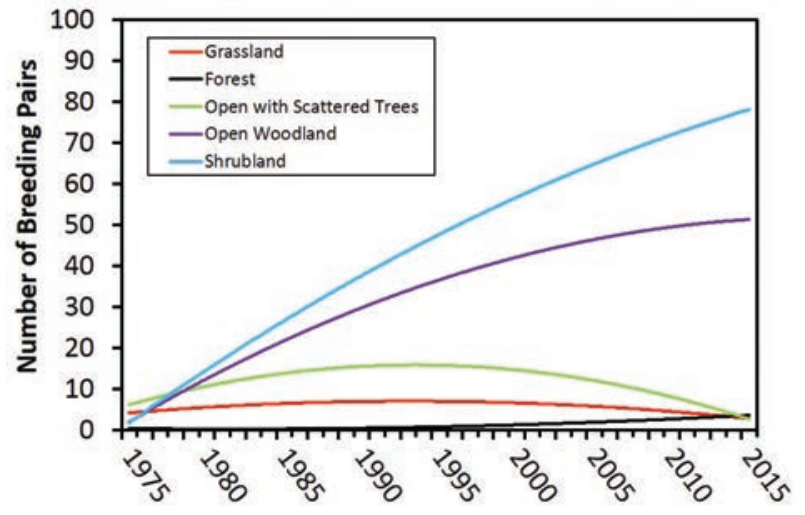

Figure 4. Changes in the number of indicated pairs of breeding birds associated with different habitat types (see Appendix B) at Kantrud's Woodlot in Stutsman County, North Dakota, 1975-2015.

In general, the number of bird species $(y=3.866+$ 1.6o9year - 0.027year $\left.{ }^{2} ; R^{2}=0.856\right)$ and the number of breeding pairs $\left(y=8.354+6.4\right.$ year -0.079 year $^{2} ; R^{2}=$ o.803) increased through time (Fig. 3). The number of species varied from four bird species in 1975 to 33 in 1999, and abundance ranged from 13 indicated breeding pairs in 1975 to 177 in 2008. On average, we observed 11.1 species (42.1 breeding pairs) per year between 1975 and $1984,22.8$ species ( 84.2 breeding pairs) per year between 1985 and 1994, 27.2 species (124.4 breeding pairs) per year between 1995 and 2004, and 26.1 species (136 breeding pairs) per year between 2005 and 2015 (Fig. 3). In increasing order, the four most abundant species were mourning dove $(\mathrm{x}=7.4$ pairs/year), yellow warbler $(\mathrm{x}=9.8$ pairs/year), American goldfinch ( $\mathrm{x}=13.5$ pairs/year), and clay-colored sparrow ( $x=18.9$ pairs/year). The mourning dove, clay-colored sparrow, brown-headed cowbird, and American goldfinch were recorded in 38 or more of the 40 years in which bird surveys were conducted. Nine $(14.5 \%)$ of the 62 species were recorded in only one of the 40 years of surveys, and seven (11.3\%) species were recorded in only two of those years (Appendix B).

The number of breeding pairs of grassland bird species remained relatively constant $(y=3.898+0.334$ year - o.oogyear ${ }^{2} ; R^{2}=0.131$ ), but these species were uncommon throughout the four decades after woody vegetation was first established (Fig. 4). The number of pairs of species associated with open areas with scattered trees or shrubs increased during the first half of the study but declined during the second half of the study ( $y=5.133$ +1.108 year -0.029 year $\left.{ }^{2} ; R^{2}=0.244\right)$. Species associated with shrubland $\left(y=-0.863+2.718\right.$ year -0.0193 year $^{2}$;

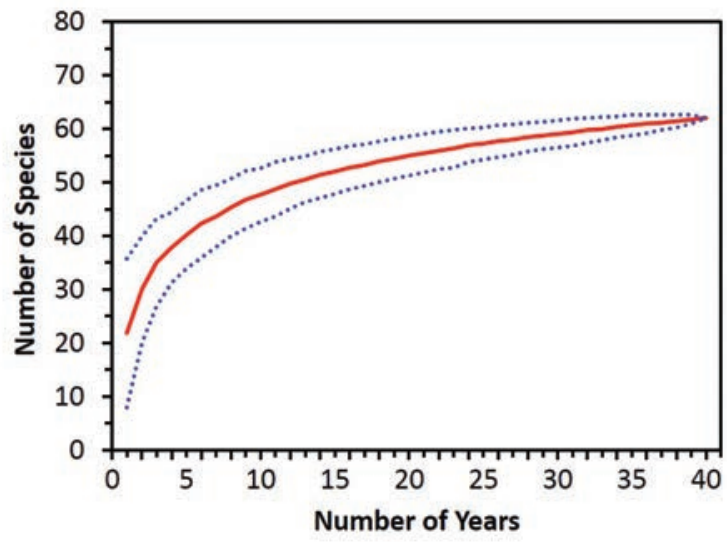

Figure 5. Accumulation of 62 species of breeding birds across 40 years of surveys at Kantrud's Woodlot in Stutsman County, North Dakota, 1975-2015 (no birds were surveyed in 1985). Solid red line indicates mean species richness values, and blue dotted lines represent \pm 1 standard deviation.

$\left.R^{2}=0.777\right)$ and open woodlands and edges $(\mathrm{y}=-0.204$ +2.277 year -0.025 year $^{2} ; R^{2}=0.822$ ) have shown the greatest increases in abundance during the 41-year period. Species associated with forest habitats $(y=0.452-$ 0.045 year +0.003 year $^{2} ; R^{2}=0.559$ ) were rare throughout the 41-year period but have been increasing during the recent two decades (Fig. 4).

The four estimators for extrapolated species richness consistently estimated higher species richness than the observed species richness $(n=62)$ (Fig. 5). Species richness estimates were 71.75 bird species for first-order Jackknife estimator, 75.70 species for second-order Jackknife estimator, 70.33 species for Chao 2 estimator (classic form), and 68.27 species for Chao 2 estimate (bias-corrected form). Thus, the observed number of species $(n=62)$ was $10.1 \%-22.1 \%$ lower than the estimated number of species, indicating that the number of species will probably continue to rise with additional years of surveys (Fig. 5).

\section{Vegetation}

Overall, between 1975 and 2015, 103 species or varieties of native $(n=48)$ and non-native $(n=55)$ trees, shrubs, or vines were planted in Kantrud's Woodlot. In addition, four native species (Symphoricarpus occidentalis, Juniperus virginiana, Rubus occidentalis, and Rosa woodsii) colonized the study site naturally (Appendix A), most likely through dispersal by birds and other animals 


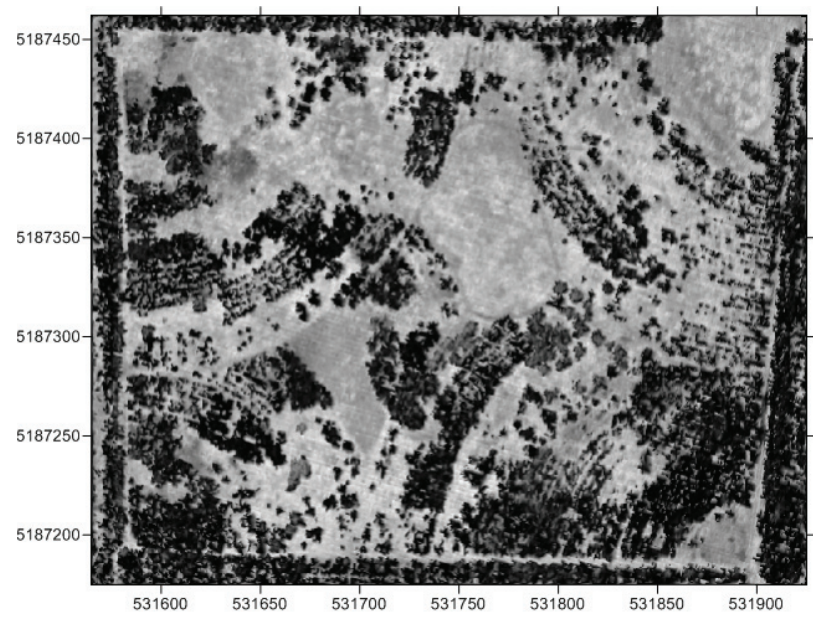

Figure 6. Shaded relief of first-returns LiDAR heights for Kantrud's Woodlot in Stutsman County, North Dakota, based on Triangulated Irregular Network (TIN) interpolation with $0.5 \mathrm{~m}$ resolution (UTM zone 14, NAD83-2007, NAVD88). North is toward the top of the image.

(i.e., zoochory). Vegetation surveys in 2016 indicated that $58.2 \%$ of the 103 planted species of woody vegetation have survived in Kantrud's Woodlot, including some species that were presumed to have perished soon after planting (e.g., yucca [Yucca glauca]). Survival of planted native and non-native species was comparable; $58.2 \%$ of nonnative species and $58.3 \%$ of native species survived. Some native species (e.g., Virginia creeper [Parthenocissus quinquefolia]) also colonized the woodlot naturally after the initial planting in another location in the woodlot did not survive and reproduce. In 2015 several dozen white spruce (Picea glauca) seedlings were discovered near mature trees of this species, representing the first cases of natural reproduction by this genus in North Dakota (Kantrud, pers. obs.). Voucher specimens of the seedlings were deposited in the three largest herbaria in North Dakota (i.e., North Dakota State University, University of North Dakota, and Northern Prairie Wildlife Research Center) in 2016.

Within the woodlot, there were 122,066 total LiDAR returns (i.e., points), of which $82 \%, 17 \%$, and $1 \%$ were first, second, and third returns, respectively. In 2016 the total tree-and-shrub canopy closure in the woodlot was $37.1 \%$ (i.e., 45,325 of the 122,066 returns did not penetrate the canopy to the ground). Mean canopy height for all vegetation classified as first returns was $6.36 \mathrm{~m}$, with a maximum vegetation height of $21.71 \mathrm{~m}$. The proportion of returns (i.e., points within an $x y z$ point-cloud) that fell within the canopy height profiles is depicted in a shaded relief map in Figure 6. There was large heteroge-
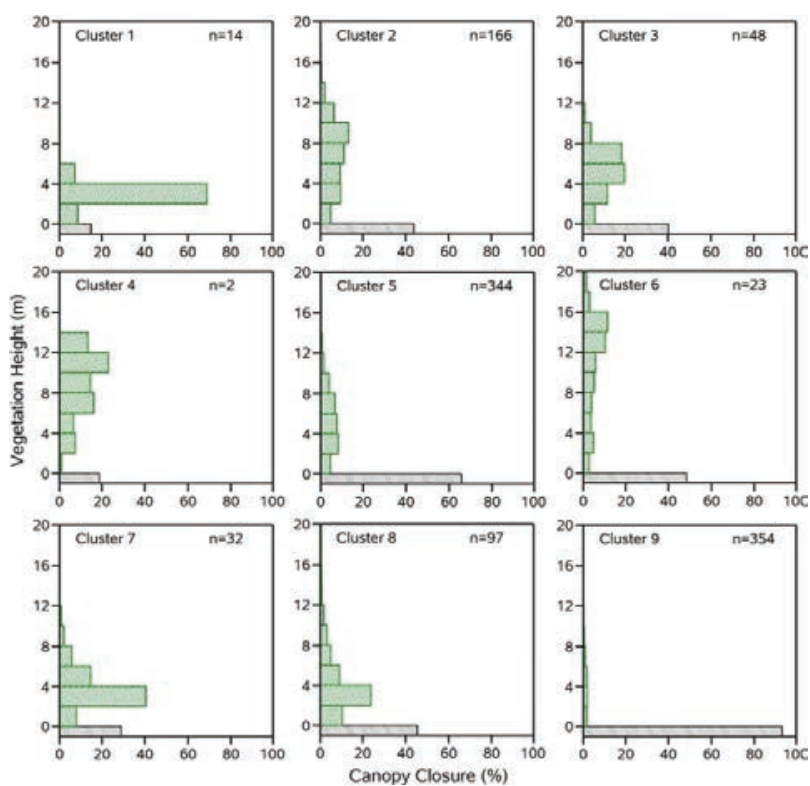

Figure 7. Mean canopy closure (\%) in nine vertical profile clusters across $108010 \times 10$ m cells in Kantrud's Woodlot in Stutsman County, North Dakota. The lower gray-shaded bar indicates LiDAR ground returns, and the upper green-shaded bars represent aboveground (i.e., vegetation) LiDAR returns.

neity in the vertical profiles among the $10 \mathrm{~m}$ cells, varying from little canopy cover (e.g., Cluster 9 in Fig. 7) to heavy canopy cover (e.g., Clusters 1, 4, and 7 in Fig. 7 ) at all vertical heights. Thirty percent of the 1,080 10-m cells were nearly devoid of all woody vegetation above 1-2 $\mathrm{m}$. Only $2 \%$ of the $1,08010-\mathrm{m}$ cells included the tallest canopies (e.g., Cluster 6 in Fig. 7).

\section{Discussion}

At least 220 species of birds have been confirmed as breeders in North Dakota (Igl, unpubl. data); we observed 62 breeding bird species in Kantrud's Woodlot over the 41-year study period. Situated in the geographic center of North America, the breeding avifauna of North Dakota is enriched by a diverse assemblage of species with northern, eastern, western, and southern distributions in North America (Stewart 1975; Johnsgard 1979). Birds associated with woody vegetation are a disproportionately large component of the North Dakota's avifaunal diversity (Igl and Johnson 1997; Igl et al. 1999), representing more bird species than all other vegetation types (see also Ohmart 1994). Igl and Johnson (1997) reported that $44.4 \%-45.7 \%$ of the breeding bird 
species and $22.4 \%-34.9 \%$ of the breeding bird pairs in North Dakota favored habitats with woody vegetation, despite that these habitats only cover $3 \%-4 \%$ of the state's landscape. Forty-four (71\%) of the 62 breeding bird species recorded in Kantrud's Woodlot favor habitats with some component of woody vegetation.

Natural woodlands and riparian forests in the northern Great Plains have been eradicated or degraded since Euro-American settlement (Stewart 1975; Johnson et al. 1976; Hesse 1996; Dixon et al. 2012). River engineering, agriculture, urbanization, exotic plant species, and imported insect pests and tree diseases (e.g., Dutch elm disease [Ophiostoma ulmi]) were important causes of the decline of riparian forest health in this region (Johnson et al. 2012). Historically, the riparian forest of the James River floodplain in south-central North Dakota was composed predominantly of a few species of late-successional trees (American elm [Ulmus americana], green ash [Fraxinus pennsylvanica], and boxelder [Acer negundo]) and a few species of native shrubs (e.g., American black currant [Ribesamericanum], nannyberry [Viburnum lentago]) (Stewart 1975). The diversity of woody plants in Kantrud's Woodlot is likely much higher than the riparian forest of the nearby James River floodplain (Appendix A).

Despite the higher diversity of woody species, the current breeding bird community in Kantrud's Woodlot largely resembles that of the nearby James River floodplain forest, although the lack of comparable bird surveys in nearby native woodlands precluded a direct comparison. Stewart (1975) divided the avifauna of the James River floodplain forest into three categories: primary and secondary intraneous species and extraneous species. Intraneous species were defined as those that appear to be capable of satisfying all or most of their essential breeding habitat requirements within the James River floodplain forest. Primary intraneous bird species often are common or abundant, and secondary intraneous species are those of lesser numerical status. Extraneous species are species that often occur in the James River floodplain forest but appear to require other plant communities to satisfy most of their breeding habitat requirements. Stewart (1975) listed 22 primary intraneous bird species, 15 secondary intraneous species, and three extraneous species of the James River floodplain forest. Of the 40 species listed by Stewart (1975) in the James River floodplain forest, only six species were not recorded in Kantrud's Woodlot during the 41-year period (Appendix B), including one primary intraneous species (white-breasted nuthatch [Sitta carolinensis]), four secondary extraneous species (eastern screech-owl [Megascops asio], European starling [Sturnus vulgaris], indigo bunting [Passerina cyanea], and lark sparrow [Chondestes grammacus]), and one extraneous species (wood duck [Aix sponsa]). In recent years, the eastern screech-owl, lark sparrow, and indigo bunting are rarely reported in Stutsman County during the breeding season (Igl, pers. obs.; see also http://ebird.org/ebird /subnational2/US-ND-093?yr=all).

This long-term study highlights the changes in a breeding bird community following the establishment of a diverse stand of woody vegetation. Establishment of planted woodlands is a long-term process and investment, and this study reinforces that it may take several decades to attain the vegetation structure and habitat complexity-and concomitantly the breeding bird community-found in natural woodlands and native riparian habitats in this region. The avian community in Kantrud's Woodlot increased in abundance and diversity over time as the planted shrubs and trees developed (Figs. 3, 4, and 5), which is typical for anthropogenic woodlands as they mature (Kujawa 2004; Mize et al. 2008). However, the increases in overall bird abundance and richness masked the responses of the different avian ecological groups (e.g., species associated with open habitats with scattered trees and shrubs) as successional changes occurred over the 41-year period. The small food plots and grassy openings comprised $33 \%$ within the woodlot (Cluster 9 in Fig. 7), allowing some grasslandbreeding species (e.g., ring-necked pheasant, uplandnesting waterfowl, western meadowlark) to persist, but as expected, abundance of grassland species remained low throughout the 41-year period. The abundance of species associated with open habitats with scattered trees and shrubs (i.e., savanna species such as kingbirds) increased initially during the first 20 years of establishment of woody vegetation but declined in the recent two decades (Fig. 4). These population changes likely reflect that the canopies of some shrub and tree plantings have matured and are closing in recent years (e.g., Cluster 1 in Fig. 7), and thus may no longer be capable of supporting savanna bird species. Brady and Noske (2010) noted a similar pattern with grassland and savanna species associated with restored woodlands in rehabilitated mine lands in Australia. In Kantrud's Woodlot, the abundance of species associated with shrubland habitat (e.g., claycolored sparrow) and those in open woodlands and edges (e.g., American goldfinch) increased throughout the 
survey period. These population increases likely reflect the increases in and preponderance of shrubland, open woodland, and edge habitats in the woodlot (e.g., Clusters 1,3 , and 7 in Fig. 7 ).

Forest bird species remained uncommon throughout the 41-year period, but their abundance has increased over time, especially in recent years, as trees matured. After four decades, the taller species of trees (e.g., cottonwood, green ash, American elm, spruce, and pine) are now sufficiently developed (Clusters 2, 3, 4, and 6 in Fig. 7) and permitted colonization by some forest bird species (e.g., eastern wood pewee, great crested flycatcher, yellow-throated vireo).

The long-term effectiveness of woodland plantings for birds is poorly known, especially in the northern Great Plains. Some studies have reported similar successional increases in bird abundance and diversity as woody plantings increase in complexity and maturity from grasses and forbs to shrubs to open woodlands and then forests (Johnston and Odum 1956; Conner and Adkisson 1975; Dickson and Segelquist 1979; Dickson et al. 1984, 1993; Mize et al. 2004; Brady and Noske 2010). As Kantrud's Woodlot continues to mature, we expect colonization by additional bird species associated with forests, shrublands, and open woodlands and edges in the region. For example, four secondary cavity-nesting species (wood duck, eastern screech-owl, white-breasted nuthatch, European starling) found in the James River floodplain (Stewart 1975) were absent from Kantrud's Woodlot since planting of woody vegetation began. These species are disproportionately dependent on larger trees for natural cavities or cavities excavated by primary cavity nesters (e.g., woodpeckers and flickers), and we would expect these species to colonize the woodlot in future years, which is reflected in the four extrapolated estimates of species richness. Brady and Noske (2010) also noted the absence of some cavity-nesting species in restored woodlands.

\section{Conservation Implications}

It is widely recognized that anthropogenic woodlands produce a variety of economic and environmental benefits, including protection of crops, livestock, and buildings; alteration of wind flow, snow drift, and snow accumulation; carbon storage; reduction in wind and water erosion; scenic beauty; visual barriers; and wildlife habitat (Mize et al. 2008). It also is widely acknowledged that planting trees and shrubs in the Great Plains contributes to the vegetative complexity and the avifaunal diversity of this region, especially in intensively farmed areas (Martin and Vohs 1978; Emmerich and Vohs 1978, 1982; Yahner 1982; Cable et al. 1992; Knopf 1994). Undoubtedly, the increases in the coverage of woody vegetation in this region have had a positive influence on the avifauna associated with trees and shrubs (Stewart 1975; Houston 1979, 1986; Houston and Bechard 1983; Knopf 1994; Igl and Johnson 1997; Igl et al. 1999; Sauer et al. 2014), including some bird species that were rare at the time of settlement (e.g., red-tailed hawk: Houston and Bechard 1983; mourning dove: Houston 1986; western kingbird: Houston 1979) and some species that historically did not occur within the state or region (e.g., pileated woodpecker [Dryocopus pileatus]: Dechant 2001; northern mockingbird [Mimus polyglottos]: Igl and Martin 2002).

This study reinforces the value of anthropogenic woodlands for birds in the Great Plains. Anthropogenic woodlands, such as Kantrud's Woodlot, have the potential to partially offset losses or degradation of riparian forests and other natural woodland habitat in this region for breeding birds that favor woody vegetation (e.g., Cassel and Wiehe 1980; Yahner 1982, 1983; Liu and Swanson 2014a, 2014b). Indeed, Kantrud's Woodlot supports several species of birds that are showing long-term (1967-2014) population declines in North Dakota, including northern flicker $(-2.04 \%$ year $)$, Baltimore oriole ( $-1.77 \%$ /year), common yellowthroat $(-0.85 \% /$ year $)$, brown thrasher $(-1.49 \% /$ year $)$, and eastern wood-pewee $(-1.18 \% /$ year) (Sauer et al. 2014).

Admittedly, more information is needed concerning how bird populations in Kantrud's Woodlot compare to the current breeding bird community in the riparian forests of the nearby James River floodplain. Several studies have reported that natural riparian forests generally support higher bird species diversity during the breeding season than planted woodlands (e.g., shelterbelts and windbreaks; Emmerich and Vohs 1982; Bakker and Higgins 2003; Kelsey et al. 2006; Kirby et al. 2009). This, in part, reflects the greater diversity in trees and shrubs in natural woodlands than in most planted woodlands, shelterbelts, and windbreaks. Knopf and Samson (1997), however, cautioned conservationists against overemphasizing the total number of bird species over biological diversity and integrity of native habitats in the Great Plains. Other authors have cautioned whether the ecological costs of planting trees in 
this region outweigh the economic and environmental benefits (Emmerich and Vohs 1982; Bakker and Higgins 2003; Kelsey et al. 2006). For example, habitat changes that improve conditions for some species may have a negative effect on other species. Our results indicate that grassland birds likely did not benefit from the establishment of woody vegetation in Kantrud's Woodlot, but many species associated with woody vegetation did benefit. Loss, degradation, and fragmentation of grasslands have been implicated in the population declines of many native grassland birds (Knopf 1994), including those in North Dakota (Igl and Johnson 1997; Grant et al. 2004). Grassland species vary in their use, tolerance, and avoidance of woody vegetation (Delisle and Savidge 1997; Helzer 1996; O'Leary and Nyberg 2000; Winter et al. 2000; Browder et al. 2002; Grant et al. 2004; Igl et al. 2008), and many grassland species likely have been adversely affected by an increase in woody vegetation in this region since settlement.

Nonetheless, the results of this study demonstrate the value of long-term studies to help understand the successional dynamics of bird populations after the establishment of woody vegetation. This study and similar long-term evaluations of anthropogenic woodlands also are important for informing decisions about restoration efforts of natural woodlands, such as establishing native riparian corridors and setting expectations for the time scale required for the return of different assemblages of woodland birds (Lindenmayer et al. 2016). The ecological importance of long-term successional changes of bird populations in anthropogenic woodlands has received little attention in the ornithological or ecological literature.

\section{Appendixes}

Appendix A. Native and non-native trees, shrubs, and vines planted (or naturally colonized) in Kantrud's Woodlot between 1975 and 2015. Planted species are sorted by the first year that they were planted. Vernacular and scientific plant names follow the Integrated Taxonomic Information System (http://www.itis.gov) or, in a few cases, the US Department of Agriculture's Plants Database (http://plants.usda.gov/).

\begin{tabular}{|c|c|c|c|c|}
\hline Common name(s) & Scientific name & Nativity in North Dakota ${ }^{a}$ & Year first planted & Survival in 2016 \\
\hline American elm & Ulmus americana $\mathrm{L}$. & Native & 1975 & Yes \\
\hline American plum & Prunus americana Marshall & Native & 1975 & Yes \\
\hline Amur maple & Acer ginnala Maxim. & Non-native & 1975 & Yes \\
\hline $\begin{array}{l}\text { Arnold hawthorn / } \\
\text { Downy Hawthorn }\end{array}$ & $\begin{array}{l}\text { Crataegus mollis (Torr. \& A. Gray) } \\
\text { Scheele }\end{array}$ & Native & 1975 & Yes \\
\hline $\begin{array}{l}\text { Boxelder / Manitoba } \\
\text { maple }\end{array}$ & Acer negundo L. & Native & 1975 & Yes \\
\hline Bur oak & Quercus macrocarpa Michx. & Native & 1975 & Yes \\
\hline Colorado blue spruce & Picea pungens Engelm. & Non-native & 1975 & Yes \\
\hline Common chokecherry & Prunus virginiana L. & Native & 1975 & Yes \\
\hline Common hackberry & Celtis occidentalis $\mathrm{L}$. & Native & 1975 & Yes \\
\hline Common lilac & Syringa vulgaris L. & Non-native & 1975 & Yes \\
\hline Dropmore elm & Ulmus pumila L. "Dropmore" & Non-native & 1975 & Yes \\
\hline Golden currant & Ribes aureum Pursh & Native & 1975 & Yes \\
\hline Great Plains yucca & Yucca glauca Nutt. & Native & 1975 & Yes \\
\hline Green ash & Fraxinus pennsylvanica Marsh. & Native & 1975 & Yes \\
\hline Hansen hedge rose & $\begin{array}{c}\text { Rosa rugosa Thunb. } \times \text { R. woodsii } \\
\text { Lindl. }\end{array}$ & Non-native & 1975 & Yes \\
\hline $\begin{array}{l}\text { Juneberry / Saskatoon } \\
\text { serviceberry }\end{array}$ & $\begin{array}{l}\text { Amelanchier alnifolia (Nutt.) Nutt. } \\
\text { ex M. Roem. }\end{array}$ & Native & 1975 & Yes \\
\hline $\begin{array}{l}\text { Laurel willow / } \\
\text { Laurel-leaf willow }\end{array}$ & Salix pentandra L. & Non-native & 1975 & No \\
\hline
\end{tabular}




\begin{tabular}{|c|c|c|c|c|}
\hline Common name(s) & Scientific name & Nativity in North Dakota & Year first planted & Survival in 2016 \\
\hline $\begin{array}{l}\text { Manchurian Crabapple } \\
\text { / Midwest crabapple }\end{array}$ & $\begin{array}{c}\text { Malus mandshurica (Maxim.) } \\
\text { Kom. "Midwest" }\end{array}$ & Non-native & 1975 & Yes \\
\hline Nanking cherry & Prunus tomentosa Thunb. & Non-native & 1975 & Yes \\
\hline $\begin{array}{l}\text { Northwest poplar / } \\
\text { Balm-of-gilead }\end{array}$ & $\begin{array}{c}\text { Populus } \times \text { jackii Sarg. }[\text { Populus } \\
\text { deltoides } \times \text { P. balsamifera] }\end{array}$ & Non-native & 1975 & Yes \\
\hline Ponderosa pine & $\begin{array}{c}\text { Pinus ponderosa Douglas ex P. } \\
\text { Lawson \& C. Lawson }\end{array}$ & Native & 1975 & Yes \\
\hline Redosier dogwood & Cornus sericea $\mathrm{L}$. & Native & 1975 & Yes \\
\hline Russian almond & Prunus tenella Batsch & Non-native & 1975 & Yes \\
\hline Russian olive & Elaeagnus angustifolia L. & Non-native & 1975 & Yes \\
\hline Scots pine / Scotch pine & Pinus sylvestris L. & Non-native & 1975 & No \\
\hline $\begin{array}{l}\text { Shiny cotoneaster / } \\
\text { Hedge cotoneaster }\end{array}$ & Cotoneaster lucidus Schltdl. & Non-native & 1975 & Yes \\
\hline Siberian crabapple & Malus baccata (L.) Borkh. & Non-native & 1975 & Yes \\
\hline Siberian elm & Ulmus pumila L. & Non-native & 1975 & Yes \\
\hline Siberian peashrub & Caragana arborescens Lam. & Non-native & 1975 & Yes \\
\hline $\begin{array}{l}\text { Silver maple / Soft } \\
\text { maple }\end{array}$ & Acer saccharinum L. & Native & 1975 & No \\
\hline Silverberry & $\begin{array}{l}\text { Elaeagnus commutata Bernh. ex } \\
\text { Rydb. }\end{array}$ & Native & 1975 & No \\
\hline $\begin{array}{l}\text { Siouxland eastern } \\
\text { cottonwood }\end{array}$ & $\begin{array}{l}\text { Populus deltoides W. Bartram ex } \\
\text { Marsh. "Siouxland" }\end{array}$ & Native & 1975 & Yes \\
\hline $\begin{array}{l}\text { Skunkbush sumac / } \\
\text { Fragrant sumac }\end{array}$ & Rhus aromatica Aiton & Native & 1975 & Yes \\
\hline Tatarian honeysuckle & Lonicera tatarica $\mathrm{L}$. & Non-native & 1975 & Yes \\
\hline Villous lilac / Late lilac & Syringa villosa Vahl & Non-native & 1975 & Yes \\
\hline Western sandcherry & Prunus pumila L. & Native & 1975 & Yes \\
\hline White poplar & Populus alba L. & Non-native & 1975 & Yes \\
\hline Yellow chokecherry & $\begin{array}{c}\text { Prunus virginiana } f \text { xanthocarpa } \\
\text { Sarg. }\end{array}$ & Native & 1975 & Yes \\
\hline Cherry prinsepia & $\begin{array}{c}\text { Prinsepia sinensis (Oliv.) Oliv. ex } \\
\text { Bean }\end{array}$ & Non-native & 1976 & Yes \\
\hline $\begin{array}{l}\text { Chinese pear / Ussurian } \\
\text { pear / Harbin pear }\end{array}$ & Pyrus ussuriensis Maxim. & Non-native & 1976 & Yes \\
\hline $\begin{array}{l}\text { European bird cherry / } \\
\text { Mayday tree }\end{array}$ & Prunus padus L. & Non-native & 1976 & Yes \\
\hline $\begin{array}{l}\text { European dwarf cherry } \\
\text { / Mongolian cherry }\end{array}$ & Prunus fruticosa Pall. & Non-native & 1976 & Yes \\
\hline Kentucky coffeetree & Gymnocladus dioica (L.) K. Koch & Non-native & 1976 & Yes \\
\hline Pin cherry & Prunus pensylvanica L. & Native & 1976 & No \\
\hline Rosybloom crabapple & $\begin{array}{l}\text { Malus pumila Mill. } \times \text { M. baccata } \\
\text { (L.) Borkh. "Rosybloom" }\end{array}$ & Non-native & 1976 & Yes \\
\hline Seabuckthorn & Hippophae rhamnoides $\mathrm{L}$. & Non-native & 1976 & No \\
\hline $\begin{array}{l}\text { Sloe / Slow plum / } \\
\text { Blackthorn }\end{array}$ & Prunus spinosa $\mathrm{L}$. & Non-native & 1976 & No \\
\hline Black walnut & Juglans nigra L. & Native & 1978 & Yes \\
\hline
\end{tabular}




\begin{tabular}{|c|c|c|c|c|}
\hline Common name(s) & Scientific name & Nativity in North Dakota ${ }^{a}$ & Year first planted & Survival in 2016 \\
\hline Eastern cottonwood & $\begin{array}{c}\text { Populus deltoides W. Bartram ex } \\
\text { Marsh. }\end{array}$ & Native & 1978 & Yes \\
\hline $\begin{array}{l}\text { Manchurian apricot / } \\
\text { Hardy apricot }\end{array}$ & Prunus armeniaca $\mathrm{L}$. & Non-native & 1978 & Yes \\
\hline Silver buffaloberry & Shepherdia argentea (Pursh) Nutt. & Native & 1978 & Yes \\
\hline White Spruce & Picea glauca (Moench) Voss & Non-native & 1978 & Yes \\
\hline $\begin{array}{l}\text { White willow / Golden } \\
\text { willow }\end{array}$ & Salix alba L. & Non-native & 1978 & Yes \\
\hline $\begin{array}{l}\text { Canadian poplar / } \\
\text { Robusta poplar }\end{array}$ & $\begin{array}{c}\text { Populus } \times \text { canadensis } \text { Moench } \\
{[\text { Populus deltoides } \times \text { P. nigra }]}\end{array}$ & Non-native & 1979 & No \\
\hline American red raspberry & Rubus idaeus L. & Native & 1986 & No \\
\hline Honey locust & Gleditisia triacanthos $\mathrm{L}$. & Native & 1986 & Yes \\
\hline $\begin{array}{l}\text { American basswood / } \\
\text { American linden }\end{array}$ & Tilia americana $\mathrm{L}$. & Native & 1991 & No \\
\hline American black currant & Ribes americanum Mill. & Native & 1991 & No \\
\hline $\begin{array}{l}\text { American elder / Com- } \\
\text { mon elderberry }\end{array}$ & Sambucus nigra L. & Native & 1991 & No \\
\hline American hazelnut & Corylus americana Walter & Native & 1991 & No \\
\hline $\begin{array}{l}\text { American } \\
\text { mountain-ash }\end{array}$ & Sorbus americana Marsh. & Non-native & 1991 & No \\
\hline Butternut & Juglans cinerea $\mathrm{L}$. & Non-native & 1991 & No \\
\hline $\begin{array}{l}\text { Common buckthorn / } \\
\text { European buckthorn }\end{array}$ & Rhamnus cathartica $\mathrm{L}$. & Non-native & 1991 & Yes \\
\hline Common pricklyash & Zanthoxylum americanum Mill. & Native & 1991 & Yes \\
\hline Littleleaf linden & Tilia cordata Mill. & Non-native & 1991 & Yes \\
\hline Quaking aspen & Populus tremuloides Michx. & Native & 1991 & No \\
\hline Staghorn sumac & Rhus typhina $\mathrm{L}$. & Non-native & 1991 & No \\
\hline Virginia creeper & $\begin{array}{c}\text { Parthenocissus quinquefolia (L.) } \\
\text { Planch. }\end{array}$ & Native & 1991 & Yes \\
\hline Wild grape & Vitis riparia Michx. & Native & 1991 & No \\
\hline Balsam poplar & Populus balsamifera L. & Native & 1995 & No \\
\hline American chestnut & Castanea dentata (Marsh.) Borkh. & Non-native & 1996 & No \\
\hline $\begin{array}{l}\text { American } \\
\text { cranberrybush / } \\
\text { Highbush cranberry }\end{array}$ & $\begin{array}{l}\text { Viburnum opulus L. var. america- } \\
\text { num Aiton }\end{array}$ & Native & 1996 & No \\
\hline American witchhazel & Hamamelis virginiana $\mathrm{L}$. & Non-native & 1996 & No \\
\hline Amur maackia & $\begin{array}{c}\text { Maackia amurensis Rupr. \& } \\
\text { Maxim. }\end{array}$ & Non-native & 1996 & No \\
\hline Black locust & Robinia pseudoacacia L. & Native & 1996 & No \\
\hline $\begin{array}{l}\text { Chinese chestnut / } \\
\text { Meader chestnut }\end{array}$ & Castanea mollissima Blume & Non-native & 1996 & No \\
\hline Common persimmon & Diospyros virginiana L. & Non-native & 1996 & No \\
\hline English oak & Quercus robur $\mathrm{L}$. & Non-native & 1996 & Yes \\
\hline $\begin{array}{l}\text { English walnut / } \\
\text { Russian walnut }\end{array}$ & Juglans regia L. & Non-native & 1996 & Yes \\
\hline
\end{tabular}




\begin{tabular}{|c|c|c|c|c|}
\hline Common name(s) & Scientific name & Nativity in North Dakota ${ }^{a}$ & Year first planted & Survival in 2016 \\
\hline $\begin{array}{l}\text { European white birch / } \\
\text { Silver birch }\end{array}$ & Betula pendula Roth & Non-native & 1996 & No \\
\hline $\begin{array}{l}\text { Hazelbert [Hazelnut } \times \\
\text { Filbert] }\end{array}$ & $\begin{array}{c}\text { Corylus americana Walter } \times C \text {. } \\
\text { avellana } \mathrm{L} .\end{array}$ & Non-native & 1996 & No \\
\hline Northern red oak & Quercus rubra L. & Non-native & 1996 & No \\
\hline Shagbark hickory & Carya ovata (Mill.) K. Koch & Native & 1996 & No \\
\hline $\begin{array}{l}\text { Southern arrowwood / } \\
\text { Arrowwood viburnum }\end{array}$ & Viburnum dentatum $\mathrm{L}$. & Non-native & 1996 & No \\
\hline Sugar maple & Acer saccharum Marsh. & Native & 1996 & No \\
\hline $\begin{array}{l}\text { White mulberry / } \\
\text { Russian mulberry }\end{array}$ & Morus alba L. & Non-native & 1996 & No \\
\hline White oak & Quercus alba $\mathrm{L}$. & Non-native & 1996 & No \\
\hline Jack pine & Pinus banksiana Lamb. & Native & 1998 & Yes \\
\hline Paper birch & Betula papyrifera Marsh. & Native & 1998 & No \\
\hline Tamarack & Larix laricina (Du Roi) K. Koch & Non-native & 1998 & Yes \\
\hline Black cherry & Prunus serotina Ehrh. & Native & 2000 & No \\
\hline Eastern white pine & Pinus strobus (L.) Small & Non-native & 2000 & No \\
\hline Norway spruce & Picea abies (L.) Karst. & Non-native & 2000 & Yes \\
\hline Ohio buckeye & Aesculus glabra Willd. & Non-native & 2000 & No \\
\hline Siberian larch & Larix sibirica Ledeb. & Non-native & 2000 & No \\
\hline Smooth sumac & Rhus glabra L. & Native & 2000 & No \\
\hline American bittersweet & Celastrus scandens L. & Native & 2002 & No \\
\hline False indigo & Amorpha fruticosa $\mathrm{L}$. & Native & 2002 & Yes \\
\hline $\begin{array}{l}\text { Rocky Mountain } \\
\text { juniper }\end{array}$ & Juniperus scopulorum Sarg. & Native & 2002 & Yes \\
\hline Red elderberry & Sambucus racemosa $\mathrm{L}$. & Native & 2005 & Yes \\
\hline Freeman's maple & $\begin{array}{c}\text { Acer } \times \text { freemanii A. E. Murray } \\
{[\text { rubrum } \times \text { saccharinum }]}\end{array}$ & Non-native & 2008 & No \\
\hline Nannyberry & Viburnum lentago L. & Native & 2008 & Yes \\
\hline Sandbar willow & Salix interior Rowlee & Native & 2010 & No \\
\hline Black raspberry & Rubus occidentalis L. & Native & Natural & Yes \\
\hline Eastern redcedar & Juniperus virginiana L. & Native & Natural & Yes \\
\hline Western snowberry & $\begin{array}{c}\text { Symphoricarpos occidentalis } \\
\text { Hook. }\end{array}$ & Native & Natural & Yes \\
\hline $\begin{array}{l}\text { Wood's rose / Interior } \\
\text { rose }\end{array}$ & Rosa woodsii Lindl. & Native & Natural & Yes \\
\hline
\end{tabular}


Appendix B. Bird species observed in Kantrud's Woodlot during the breeding season between 1975 and 2015. Bird species are sorted by the first year that they were planted. Vernacular and scientific bird names follow the American Ornithologists' Union (1998) and subsequent supplements.

\begin{tabular}{|c|c|c|c|c|c|}
\hline Common name ${ }^{a}$ & Species name & $\begin{array}{c}\text { Habitat } \\
\text { association }^{\mathrm{b}}\end{array}$ & $\begin{array}{l}\text { Year of first } \\
\text { observation }\end{array}$ & $\begin{array}{l}\text { Number } \\
\text { of years }\end{array}$ & $\begin{array}{l}\text { Characteristic breeding } \\
\text { birds of the James River } \\
\text { Flood Plain }\end{array}$ \\
\hline Lark bunting (-) & Calamospiza melanocorys & Grassland & 1975 & 1 & \\
\hline Mourning dove & Zenaida macroura & Open woodland & 1975 & 38 & Primary intraneous \\
\hline Vesper sparrow & Pooecetes gramineus & Grassland & 1975 & 10 & \\
\hline Western meadowlark (-) & Sturnella neglecta & Grassland & 1975 & 16 & \\
\hline American goldfinch & Spinus tristis & Shrubland & 1976 & 39 & Primary intraneous \\
\hline Brown-headed cowbird & Molothrus ater & Open woodland & 1976 & 39 & Secondary intraneous \\
\hline Clay-colored sparrow & Spizella pallida & Shrubland & 1976 & 38 & Primary intraneous \\
\hline Common grackle $(+)$ & Quiscalus quiscula & Open with trees & 1976 & 38 & Extraneous \\
\hline Eastern kingbird & Tyrannus tyrannus & Open with trees & 1976 & 30 & \\
\hline Horned lark (-) & Eremophila alpestris & Grassland & 1976 & 3 & \\
\hline Killdeer & Charadrius vociferus & Grassland & 1976 & 7 & \\
\hline Red-winged blackbird & Agelaius phoeniceus & Grassland & 1976 & 26 & \\
\hline Western kingbird & Tyrannus verticalis & Open with Trees & 1976 & 26 & \\
\hline Dickcissel & Spiza americana & Grassland & 1978 & 5 & \\
\hline American robin $(+)$ & Turdus migratorius & Open woodland & 1979 & 31 & Primary intraneous \\
\hline Brown thrasher $(-)$ & Toxostoma rufum & Shrubland & 1979 & 33 & Secondary intraneous \\
\hline Common yellowthroat $(-)$ & Geothlypis trichas & Shrubland & 1979 & 28 & Secondary intraneous \\
\hline Gray partridge & Perdix perdix & Grassland & 1979 & 14 & \\
\hline Black-billed cuckoo (-) & Coccyzus erythropthalmus & Forest & 1980 & 14 & Primary intraneous \\
\hline Gray catbird & Dumetella carolinensis & Shrubland & 1980 & 33 & Secondary intraneous \\
\hline Orchard oriole $(+)$ & Icterus spurius & Open woodland & 1980 & 23 & \\
\hline Cedar waxwing $(+)$ & Bombycilla cedrorum & Open woodland & 1981 & 28 & Secondary intraneous \\
\hline Yellow warbler $(+)$ & Setophaga petechia & Open woodland & 1981 & 33 & Primary intraneous \\
\hline Song sparrow $(+)$ & Melospiza melodia & Shrubland & 1983 & 24 & Primary intraneous \\
\hline Mallard (+) & Anas platyrhynchos & Grassland & 1984 & 22 & Extraneous \\
\hline Willow Flycatcher $(+)$ & Empidonax traillii & Shrubland & 1984 & 30 & Secondary intraneous \\
\hline House Wren & Troglodytes aedon & Open woodland & 1986 & 27 & Primary intraneous \\
\hline Least Flycatcher $(+)$ & Empidonax minimus & Open woodland & 1986 & 26 & Primary intraneous \\
\hline Northern flicker (-) & Colaptes auratus & Open woodland & 1986 & 9 & Primary intraneous \\
\hline $\begin{array}{l}\text { Ruby-throated } \\
\text { hummingbird }\end{array}$ & Archilochus colubris & Open woodland & 1986 & 1 & \\
\hline Baltimore oriole (-) & Icterus galbula & Open woodland & 1987 & 4 & Primary intraneous \\
\hline Eastern bluebird $(+)$ & Sialia sialis & Open woodland & 1987 & 2 & Secondary intraneous \\
\hline Black-capped chickadee & Poecile atricapillus & Open woodland & 1988 & 19 & Primary intraneous \\
\hline Ring-necked pheasant $(+)$ & Phasianus colchicus & Grassland & 1988 & 25 & \\
\hline Great horned owl & Bubo virginianus & Open woodland & 1989 & 4 & Primary intraneous \\
\hline Sharp-tailed grouse & Tympanuchus phasianellus & Grassland & 1989 & 3 & \\
\hline Warbling vireo $(+)$ & Vireo gilvus & Open woodland & 1989 & 7 & Secondary intraneous \\
\hline
\end{tabular}




\begin{tabular}{|c|c|c|c|c|c|}
\hline Common name ${ }^{a}$ & Species name & $\begin{array}{c}\text { Habitat } \\
\text { association }^{\mathrm{b}}\end{array}$ & $\begin{array}{l}\text { Year of first } \\
\text { observation }\end{array}$ & $\begin{array}{l}\text { Number } \\
\text { of years }\end{array}$ & $\begin{array}{l}\text { Characteristic breeding } \\
\text { birds of the James River } \\
\text { Flood Plain }{ }^{c}\end{array}$ \\
\hline Yellow-billed cuckoo & Coccyzus americanus & Forest & 1989 & 2 & \\
\hline Rose-breasted grosbeak & Pheucticus ludovicianus & Open Woodland & 1991 & 1 & Primary intraneous \\
\hline American crow (-) & Corvus brachyrhynchos & Open Woodland & 1994 & 12 & Primary intraneous \\
\hline Northern pintail & Anas acuta & Grassland & 1995 & 4 & \\
\hline Blue-winged teal $(+)$ & Anas discors & Grassland & 1996 & 1 & \\
\hline Bobolink $(+)$ & Dolichonyx oryzivorus & Grassland & 1996 & 4 & \\
\hline Chipping sparrow $(+)$ & Spizella passerina & Open woodland & 1996 & 17 & \\
\hline Gadwall (+) & Anas strepera & Grassland & 1996 & 5 & \\
\hline Grasshopper sparrow (-) & $\begin{array}{c}\text { Ammodramus savan- } \\
\text { narum }\end{array}$ & Grassland & 1996 & 7 & \\
\hline Savannah sparrow & Passerculus sandwichensis & Grassland & 1996 & 2 & \\
\hline Blue jay & Cyanocitta cristata & Open woodland & 1998 & 8 & Secondary intraneous \\
\hline Long-eared owl & Asio otus & Open woodland & 1998 & 2 & \\
\hline Tree swallow (+) & Tachycineta bicolor & Open with trees & 1998 & 9 & \\
\hline Downy woodpecker & Picoides pubescens & Open woodland & 1999 & 11 & Primary intraneous \\
\hline Cooper's hawk & Accipiter cooperii & Forest & 2001 & 13 & Primary intraneous \\
\hline Hairy woodpecker & Picoides villosus & Open woodland & 2003 & 1 & Primary intraneous \\
\hline Swainson's hawk & Buteo swainsoni & Open with trees & 2004 & 1 & \\
\hline Wild turkey $(+)$ & Meleagris gallopavo & Forest & 2005 & 2 & \\
\hline Northern harrier & Circus cyaneus & Grassland & 2006 & 1 & \\
\hline Red-tailed hawk & Buteo jamaicensis & Open with trees & 2006 & 5 & Primary intraneous \\
\hline $\begin{array}{l}\text { Great crested flycatcher } \\
(+)\end{array}$ & Myiarchus crinitus & Forest & 2007 & 2 & Secondary intraneous \\
\hline Red-eyed vireo (+) & Vireo olivaceus & Forest & 2007 & 9 & Primary intraneous \\
\hline Eastern wood-pewee & Contopus virens & Forest & 2010 & 1 & Primary intraneous \\
\hline Yellow-throated vireo $(+)$ & Vireo flavifrons & Forest & 2010 & 2 & Secondary intraneous \\
\hline Brewer's blackbird (+) & Euphagus cyanocephalus & Open with trees & 2015 & 1 & \\
\hline
\end{tabular}

${ }^{a}$ Significant long-term (1967-2014) increasing (+) or decreasing (-) population trends in North Dakota, based on the North American Breeding Bird Survey (Sauer et al. 2014).

${ }^{\mathrm{b}}$ Bird species were categorized into a general breeding habitat association based on the literature (Ehrlich et al. 1988; Peterjohn and Sauer 1993; Igl and Johnson 1997) and personal experience.

${ }^{c}$ Characteristic breeding birds of the James River Floodplain biotic community, as defined by Stewart (1975). Intraneous species were defined as those that appear to be capable of satisfying all or most of their essential breeding habitat requirements within the James River Floodplain plant community. Primary intraneous bird species often are common or abundant, and secondary intraneous species are those of lesser numerical abundance. Extraneous species often occur in this biotic community but appear to require other communities to satisfy most of their breeding habitat.

Lawrence D. Igl (ligl@usgs.gov), US Geological Survey, Northern Prairie Wildlife Research Center, 8711 37th Street SE, Jamestown, ND 58401

Harold A. Kantrud (halka@daktel.com), current address: 3962 89th Avenue SE, Jamestown, ND 58401; former address:
US Geological Survey, Northern Prairie Wildlife Research Center, 8711 37th Street SE, Jamestown, ND 58401

Wesley E. Newton (wnewton@usgs.gov), US Geological Survey, Northern Prairie Wildlife Research Center, 8711 37th Street SE, Jamestown, ND 58401 


\section{Acknowledgments}

We thank the following individuals who assisted with bird surveys in this study: Bonita Barnes, Craig A. Faanes, Elizabeth J. Kantrud, Michael D. Schwartz, and Robert E. Stewart (deceased). Employees of the US Department of Agriculture's Natural Resources Conservation Service (formerly the Soil Conservation Service) and the Stutsman County Soil Conservation District assisted with the planning and initial planting of the woodlot. The LiDAR data were obtained from the North Dakota State Water Commission. Brian J. Chepulis and Emily C. McLean assisted with the collection shrub and tree height data in 2016 that were used to calibrate the 2010 LiDAR data. Jane E. Austin. Michael D. Schwartz, and two anonymous reviewers provided helpful suggestions and comments on an earlier draft of this manuscript. Any use of trade, firm, or product names is for descriptive purposes only and does not imply endorsement by the US government.

\section{References}

Abel, P. L., A. Gulsvig, D. L. Johnson, and J. Seaholm. 1995. Soil Survey of Stutsman County, North Dakota. Washington, DC: US Department of Agriculture, Natural Resources Conservation Service.

American Ornithologists' Union. 1998. Check-List of North American Birds, 7th ed. Washington, DC: American Ornithologists' Union.

Bakker, K. K., and K. F. Higgins. 2003. "Avian Use of Natural versus Planted Woodlands in Eastern South Dakota, USA." Natural Areas Journal 23:121-28.

Brady, C. J., and R. A. Noske. 2010. "Succession in Bird and Plant Communities over a 24-Year Chronosequence of Mine Rehabilitation in the Australian Monsoon Tropics." Restoration Ecology 18:855-64.

Browder, S. F., D. H. Johnson, and I. J. Ball. 2002. "Assemblages of Breeding Birds as Indicators of Grassland Condition." Ecological Indicators 2:257-70.

Cable, T. T., R. L. Schroeder, V. Brack Jr., and P. S. Cook. 1992. "Summer Bird Use of Kansas Windbreaks." Prairie Naturalist 24:175-84.

Cassel, J. F., and J. M. Wiehe. 1980. "Uses of Shelterbelts by Birds." In Proceedings of the Workshop on the Management of Western Forests and Grasslands for Nongame Birds, technical coordinator, R. M. Degraaf, 79-87. US Department of Agriculture, Forest Service, General Technical Report INT-86.

Chazdon, R. L., R. K. Colwell, J. S. Denslow, and M. R. Guariguata. 1998. "Statistical Methods for Estimating Species Richness of Woody Regeneration in Primary and
Secondary Rain Forests of Northeastern Costa Rica." In Forest Biodiversity Research, Monitoring and Modeling: Conceptual Background and Old World Case Studies, ed. F. Dallmeier and J. A. Comiskey, 285-309. Paris, France: Parthenon Publishing Group.

Conner, R. N., and G. S. Adkisson. 1975. "Effects of Clearcutting on the Diversity of Breeding Birds." Journal of Forestry 73:781-85.

Dahl, T. E. 1990. Wetland Losses in the United States, 1780 's to 1980's. Washington, DC: US Fish and Wildlife Service.

Dahl, T. E. 2014. Status and Trends of Prairie Wetlands in the United States 1997 to 2009. Washington, DC: US Department of the Interior, Fish and Wildlife Service, Ecological Services.

Dechant, J. A. 2001. "Range Expansion of the Pileated Woodpecker in North Dakota." Prairie Naturalist 33:163-82.

Delisle, J. M., and J. A. Savidge. 1997. "Avian Use and Vegetation Characteristics of Conservation Reserve Program Fields." Journal of Wildlife Management 61:318-25.

Dickson, J. G., R. N. Conner, and J. H. Williamson. 1984. "Bird Community Changes in a Young Pine Plantation in East Texas." Journal of Applied Forestry 8:47-51.

Dickson, J. G., R. N. Conner, and J. H. Williamson. 1993. "Breeding Bird Community Changes in a Developing Pine Plantation." Bird Populations 1:28-35.

Dickson, J. G., and C. A. Segelquist. 1979. "Breeding Bird Populations in Pine and Pine-Hardwood Forests in Texas." Journal of Wildlife Management 43:549-55.

Dieni, J. S., and S. L. Jones. 2002. "A Field Test of the Area Search Method for Measuring Breeding Bird Populations." Journal of Field Ornithology 73:253-57.

Dixon, M. D., W. C. Johnson, M. L. Scott, D. E. Bowen, and L. A. Rabbe. 2012. "Dynamics of Plains Cottonwood (Populus deltoides) Forests and Historical Landscape Change along Unchannelized Segments of the Missouri River, USA." Environmental Management 49:990-1008.

Ehrlich, P. R., D. S. Dobkin, and D. Wheye. 1988. The Birder's Handbook: A Field Guide to the Natural History of North American Birds. New York: Simon and Schuster.

Emmerich, J. M., and P. A. Vohs. 1978. "Woodland Habitat Utilization by Birds in Eastern South Dakota." In Trees, a Valuable Great Plains Multiple-Use Resource, 90-91. Proceedings of the 3oth Annual Meeting of the Forestry Committee, Great Plains Agricultural Council Publication No. 87 .

Emmerich, J. M., and P. A. Vohs. 1982. "Comparative Use of Four Woodland Habitats by Birds." Journal of Wildlife Management 46:43-49.

Fair, J., E. Paul, and J. Jones, ed. 2010. Guidelines to the Use of Wild Birds in Research. Washington, DC: Ornithological Council.

Gotelli, N. J., and R. K. Colwell. 2010. "Estimating Species Richness." In Biological Diversity: Frontiers in Measurement and Assessment, ed. A. E. Magurran and B. J. McGill, 3954. Oxford: Oxford University Press. 
Grant, T. A., and G. B. Berkey. 1999. "Forest Area and Avian Diversity in Fragmented Aspen Woodland of North Dakota. Wildlife Society Bulletin 27:904-14.

Grant, T. A., E. Madden, and G. B. Berkey. 2004. “Tree and Shrub Invasion in Northern Mixed-Grass Prairie: Implications for Breeding Grassland Birds." Wildlife Society Bulletin 32:807-18.

Hart, R. H., and J. A. Hart. 1997. "Rangelands of the Great Plains before European Settlement.” Rangelands 19:4-11.

Haugen, D. E., R. J. Piva, N. P. Kingsley, and R. A. Harsel. 1999. North Dakota's Forest Resources, 1994. Research Paper NC-136. US Department of Agriculture, Forest Service, North Central Research Station, St. Paul, MN.

Helzer, C. J. 1996. The Effects of Wet Meadow Fragmentation on Grassland Birds. MS thesis, University of Nebraska, Lincoln, NE.

Hesse, L. W. 1996. "Floral and Faunal Trends in the Middle Missouri River." In Overview of River-Floodplain Ecology in the Upper Mississippi River Basin, ed. D. L. Galat and A. G. Frazier, 73-90. Washington, DC: US Government Printing Office.

Houston, C. S. 1979. "The Spread of the Western Kingbird across the Prairies." Blue Jay 37:149-57.

Houston, C. S. 1986. "Mourning Dove Numbers Explode on the Canadian Prairie." American Birds 40:52-54.

Houston, C. S., and M. J. Bechard. 1983. "Trees and the Redtailed Hawk in Southern Saskatchewan." Blue Jay 41:99-109.

Igl, L. D., and D. H. Johnson. 1997. "Changes in Breeding Bird Populations in North Dakota: 1967 to 1992-93." Auk 114:74-92.

Igl, L. D., D. H. Johnson, and H. A. Kantrud. 1999. "Uncommon Breeding Birds in North Dakota: Population Estimates and Frequencies of Occurrence." Canadian FieldNaturalist 113:646-51.

Igl, L. D., D. H. Johnson, and H. A. Kantrud. 2008. "A Historical Perspective: Changes in Grassland Breeding Bird Densities within Major Habitats in North Dakota between 1967 and 1992-1993." In Prairie Invaders: Proceedings of the 2oth North American Prairie Conference, ed. J. T. Springer and E. C. Springer, 275-95. Kearney: University of Nebraska at Kearney.

Igl, L. D., and R. E. Martin. 2002. "Records of Northern Mockingbird, Mimus polyglottos, Occurrences in North Dakota during the Twentieth Century." Canadian FieldNaturalist 116:87-97.

Jakes, P. J., and W. B. Smith. 1982. A Second Look at North Dakota's Timberland, 1980. US Department of Agriculture, Forest Service, North Central Forest Experiment Station. Resource Bulletin NC-58.

Johnsgard, P. A. 1979. Birds of the Great Plains: Breeding Species and Their Distribution. Lincoln: University of Nebraska Press.
Johnson, R. J., and M. M. Beck. 1988. "Influences of Shelterbelts on Wildlife Management and Biology." Agriculture, Ecosystems and Environment 22/23:301-35.

Johnson, W. C., R. L. Burgess, and W. R. Keammerere. 1976. "Forest Overstory Vegetation and Environment on the Missouri River Floodplain in North Dakota." Ecological Monograph 46:59-84.

Johnson, W. C., M. D. Dixon, M. L. Scott, L. Rabbe, G. Larson, M. Volke, and B. Werner. 2012. "Forty Years of Vegetation Change on the Missouri River." BioScience 62:123-35.

Johnston, D. W., and J. M. Hagen III. 1992. "An Analysis of Long-Term Breeding Bird Censuses from Eastern Deciduous Forests." In Ecology and Conservation of Neotropical Migrant Landbirds, eds. J. M. Hagan III and D. W. Johnson, 75-84. Washington, DC: Smithsonian Institution Press.

Johnston, D. W., and E. P. Odum. 1956. "Breeding Bird Populations in Relation to Plant Succession on the Piedmont of Georgia." Ecology 37:50-62.

Kelsey, K. W., D. E. Naugle, K. F. Higgins, and K. K. Bakker. 2006. "Planting Trees in Prairie Landscapes: Do the Ecological Costs Outweigh the Benefits." Natural Areas Journal 26:254-60.

Kirby, D., D. Nilson, and K. Krabbenhoft. 2009. "Breeding Bird Selection of Restored and Native Wooded Draws in North Dakota." Rangelands 31:9-15.

Knopf, F. L. 1994. "Avian Assemblages on Altered Grasslands.” Studies in Avian Biology 15:247-57.

Knopf, F. L., and F. Samson. 1997. Ecology and Conservation of Plains Vertebrates. Ecological Studies 125. New York: Springer-Verlag.

Kujawa, K. 2004. "Importance of Young Shelterbelts for Breeding Avifauna in Agricultural Landscape (Turew Area, West Poland)." Journal of Polish Ecology 52:433-43.

Kutner, M. H., J. Neter, C. J. Nachtsheim, and W. Li. 2005. Applied Linear Statistical Models, 5 th ed. Chicago: McGraw-Hill/Irwin.

Lindenmayer, D. B., P. W. Lane, P. S. Barton, M. Crane, K. Ikin, D. Michael, and S. Okada. 2016. "Long-Term Bird Colonization and Turnover in Restored Woodlands." Biodiversity and Conservation 25:1587-1603

Liu, M., and D. L. Swanson. 2014a. "Physiological Evidence that Anthropogenic Woodlots Can Substitute for Native Riparian Woodlands as Stopover Habitat for Migrant Birds." Physiological and Biochemical Zoology 87:183-95.

Liu, M., and D. L. Swanson. 2014b. "Stress Physiology of Migrant Birds during Stopover in Natural and Anthropogenic Woodland Habitats of the Northern Prairie Region." Conservation Physiology 2 (1): couo46; doi:10.1093/conphys/couo46.

Martin, T. E., and P. A. Vohs. 1978. "Configuration of Shelterbelts for Optimum Utilization by birds." In Trees, A Valuable Great Plains Multiple-Use Resource, compilers M. 
Craighead, R. Davis, R. Gardner, and N. Smola, 79-88. Proceedings of the 3oth Annual Meeting of the Forestry Committee, Great Plains Agricultural Council Publication No. 87.

McCune, B., and M. J. Mefford. 2011. PC-ORD: Multivariate Analysis of Ecological Data. Version 6.o. MjM Software, Gleneden Beach, OR.

Mize, C. W., J. R. Brandle, M. M. Schoneberger, and G. Bentrup. 2008. "Ecological Development and Function of Shelterbelts in Temperate North America." In Toward Agroforestry Design: An Ecological Approach, ed. S. Jose and M. Gordon, 27-54. New York: Springer.

NAS (National Academy of Science). 2002. Riparian Areas: Functions and Strategies for Management. Washington, DC: National Academy Press.

Ohmart, R. D. 1994. "The Effects of Human-Induced Changes on the Avifauna of Western Riparian Habitats." Studies in Avian Biology 15:273-85.

O’Leary, C. H., and D. W. Nyberg. 200o. "Treelines between Fields Reduce the Density of Grassland Birds.” Natural Areas Journal 20:243-49.

Peterjohn, B. G., and J. R. Sauer. 1993. "North American Breeding Bird Survey Annual Summary, 1990-1991.” Bird Populations 1:52-67.

Reid, R. 1948. Lewis and Clark in North Dakota. Bismarck: State Historical Society of North Dakota.

Samson, F., and F. Knopf. 1994. "Prairie Conservation in North America." BioScience 44:418-21.

Sauer, J. R., J. E. Hines, J. E. Fallon, K. L. Pardieck, D. J. Ziolkowski Jr., and W. A. Link. 2014. The North American Breeding Bird Survey: Results and Analysis, 1966-2013. Version 01.30.2015. USGS Patuxent Wildlife Research Center, Laurel, MD. http://www.mbr-pwrc.usgs.gov/bbs /bbs.html.
Schwilling, M. D. 1982. "Nongame Wildlife and Windbreaks." In Windbreaks: What Are They Worth? Proceedings of the 34th Annual Meeting of the Forestry Committee, Dodge City, KS, 258-62. Great Plains Agricultural Council Publication No. 106.

Slater, P. J. 1994. "Factors Affecting the Efficiency of the Area Search Method of Censusing Birds in Open Forests and Woodlands." Emu 94:9-16.

Stewart, R. E. 1975. Breeding Birds of North Dakota. Fargo, ND: Tri-College Center for Environmental Studies.

Stewart, R. E., and H. A. Kantrud. 1972. "Population Estimates of Breeding Birds in North Dakota." Auk 89:766-88.

Vosselman, G., and H.-G. Maas. 2010. Airborne and Terrestrial Laser Scanning. Boca Raton, FL: CRC Press.

Watson, D. M. 2003. “The 'Standardized Search': An Improved Way to Conduct Bird Surveys." Austral Ecology 28:515-25.

Winter, M., D. H. Johnson, and J. Faaborg. 200o. "Evidence for Edge Effects on Multiple Levels in Tallgrass Prairie.” Condor 102:256-66.

Watson, D. M. 2004. "Comparative Evaluation of New Approaches to Survey Birds.” Wildlife Research 31:1-11.

Wright, H. E. Jr. 1970. "Vegetational History of the Central Plains." In Pleistocene and Recent Environments of the Central Great Plains, ed. W. Dort Jr. and J. Jones Jr. University of Kansas Special Publication 3:157-72.

Yahner, R. H. 1982. "Avian Use of Vertical Strata and Plantings in Farmstead Shelterbelts." Journal of Wildlife Management 46:50-60.

Yahner, R. H. 1983. "Seasonal Dynamics, Habitat Relationships, and Management of Avifauna in Farmstead Shelterbelts." Journal of Wildlife Management 47:85-104.

Zhang, K., and D. Whitman. 2005. "Comparison of Three Algorithms for Filtering Airborne LiDAR Data." Photogrammetric Engineering \& Remote Sensing 71:313-24. 